\title{
Concepts and Strategies of Organic Plant Breeding in Light of Novel Breeding Techniques
}

\author{
Edwin Nuijten ${ }^{1, *}$, Monika M. Messmer ${ }^{2}$ and Edith T. Lammerts van Bueren ${ }^{1,3}$ \\ 1 Louis Bolk Institute, Hoofdstraat 24, 3972 LA Driebergen, The Netherlands; \\ edith.lammertsvanbueren@wur.nl \\ 2 Research Institute of Organic Agriculture (FiBL), Department of Crop Sciences, Ackerstrasse 113, \\ CH-5070 Frick, Switzerland; monika.messmer@fibl.org \\ 3 Wageningen University and Research, Wageningen UR Plant Breeding, P.O. Box 386, 6700 AJ Wageningen, \\ The Netherlands \\ * Correspondence: e.nuijten@louisbolk.nl; Tel.: +31-343-523-860
}

Academic Editor: Gerhart U. Ryffel

Received: 10 September 2016; Accepted: 21 December 2016; Published: 23 December 2016

\begin{abstract}
In this paper, we describe the development of a set of guiding principles for the evaluation of breeding techniques by the organic sector over time. The worldwide standards of organic agriculture (OA) do not allow genetic engineering (GE) or any products derived from genetic engineering. The standards in OA are an expression of the underlying principles of health, ecology, fairness and care. The derived norms are process and not product oriented. As breeding is considered part of the process in agriculture, GE is not a neutral tool for the organic sector. The incompatibility between OA and GE is analyzed, including the "novel breeding techniques". Instead, alternative breeding approaches are pursued based on the norms and values of organic agriculture not only on the technical level but also on the social and organizational level by including other value chain players and consumers. The status and future perspectives of the alternative directions for organic breeding are described and discussed.
\end{abstract}

Keywords: organic farming; plant breeding; guiding principles; alternative techniques; future perspectives

\section{Introduction}

Pluriformity in society and agriculture are important. According to Bawden [1], a balance in paradigms is important for the development of sustainable innovations. Each paradigm implies its own view on technology development, its own presumed best solutions, but also its own weaknesses. More pluriformity means the possibility for more solution pathways to exist and for more solution pathways to develop. Paradigms have different related ways of thinking (thought styles) and underlying values [2], which can result in different breeding approaches and strategies [3]. Related to different ways of thinking (hierarchical, individualistic, and egalitarian) are also different risk perceptions and different ways of managing risk $[4,5]$. Consequently, different scientific disciplines use different methodologies and methods [6,7]. The challenges societies worldwide currently are facing with respect to food security and climate change are complex, and no blueprint is available to solve this complexity. Hisschemöller and Hoppe [8] pointed out how many societal issues lead to controversies and can be categorized as "messy" problems as it is not merely a matter of finding agreement on the technical knowledge to solve certain problems but also on the underlying values that differ among groups in societies. 
Organic agriculture is a private sector with its own developed values and standards. The organic sector is continuously developing and improving its farming and processing methods and where appropriate will adopt new strategies when they comply with the norms and standards. Specifically in the field of breeding there are different perceptions in societies on the suitability of modern breeding techniques such as genetic engineering (GE), especially for organic agriculture [9-12]. The controversies around whether or not the organic sector should adopt certain modern breeding techniques can be considered such a "messy" problem as there are not only technical aspects but also different opinions on values at stake. In this paper, we depart from the notion that there are different opinions on how to solve a problem, and that it should be possible to respect and maintain pluriformity in solution pathways in societies.

Organic agriculture $(\mathrm{OA})$ is defined by the worldwide umbrella organization International Federation of Organic Agriculture Movements (IFOAM) as a production system that sustains the health of soils, ecosystems and people, by relying on ecological processes, biodiversity and cycles adapted to local conditions, rather than the use of non-organic, chemical-synthetic inputs. OA also promotes fair relationships in the value chain, reflected in IFOAM's four basic principles of Health, Ecology, Fairness and Care [13]. IFOAM defines "sustainable" as meeting the needs of the present without compromising the ability of future generations to meet their own needs, conserving an ecological balance by avoiding depletion or destruction of natural resources [14].

$\mathrm{OA}$ is a rapidly growing sector worldwide. A total of 43.7 million hectares were organically managed by 2.3 million organic producers at the end of 2014 which is approximately $1 \%$ of the worldwide agricultural land [15]. The global sales of organic food and drink reached 80 billion US dollars in 2014 [15]. With 11.6 million hectares, Europe covers $27.6 \%$ of the world's organic farmland with the largest areas in Spain, Italy, France and Germany. This area almost doubled since 2004. The European market for organic products in 2014 was valued $€ 26.2$ billion with a growth rate of $8 \%$. European countries have top rankings for market share and per capita consumption worldwide [15]. For many countries the market demand is growing faster than domestic production. In a recent published vision of IFOAM called "Organic 3.0" it was estimated that the organic sector could potentially grow up to $20 \%$ worldwide of the total agricultural area [14].

For many years, the organic sector was considered the frontrunner of sustainable agriculture and the spin-off it had to the development of sustainability in conventional agriculture was the reason at the beginning of 2000 for many European governments to invest in OA. To maintain that leadership position of the organic sector, IFOAM calls for a continuous improvement in the sector towards more and more implementing best practices to develop "truly sustainable food and farming systems" [14]. This implies an integrated approach to make organic food and farming systems not only ecologically sound, but also economically viable, socially and culturally diverse and transparently accountable.

Organic farming systems produce on average lower yields compared with conventional agriculture. However, they are more profitable and environmentally friendly, and deliver equally or more nutritious fruits and vegetables $[16,17]$ that contain less to no chemical-synthetic pesticide residues, compared with conventional farming [18]. The future challenge is to further optimize the productivity of organic farming systems to overcome the often discussed average yield gap of approximately $20 \%$ between conventional and organic agriculture [19-21] without compromising on long term sustainability [22]. However, other authors [20,23] discuss that the $20 \%$ yield gap does not count for all crops and all regions, as in some cases there is no difference or even an opposite trend towards higher yields for organic crops (e.g., barley, wheat and hay crops). One cause of the yield gap is the fact that organic farmers often apply $50 \%-80 \%$ of nitrogen through organic fertilizers compared to the amount of nitrogen in conventional farming systems, e.g., [24,25]. While the nitrogen of organic fertilizer will be slowly released it also prevents nitrate leakage to surface and ground water. In addition, the limited nitrogen supply also reduces too luxurious growth that could enhance pests (e.g., aphids) and foliar diseases (e.g., mildew) as in cereal production [25]. Another factor of limited yield under OA is the lack of cultivars adapted to low-input growing conditions without 
the use of herbicides, pesticides and fungicides. At present, around $95 \%$ of organic production in modern societies is based on crop varieties that were bred for the conventional high-input sector where mineral nitrogen fertilization and chemical-synthetic pest, disease and weed control are not a limiting factor [26]. The fact that such varieties are used in organic farming systems does not mean that they are optimally adapted, as often important traits required under organic and low-input production conditions are still lacking [26]. Organic farmers loose potential yield due to lack of sufficient weed suppression, pest and disease resistance traits in cultivars, such as against downey mildew in onion, late blight in potato and scab in apple [25]. Various pre-breeding programs to enhance such resistances are running and first resistant cultivars are being released $[27,28]$.

All varieties of which seeds or propagation material have been propagated under organic growing conditions are currently allowed in organic agriculture, provided they are not declared as genetically modified varieties [29]. According to a derogation rule, untreated, non-organically propagated varieties are only permitted, if no suitable varieties from organic propagation are available. Among the currently available varieties the following categories can be distinguished [30]:

(1) Varieties derived from conventional plant breeding that are suitable for organic farming with the exception of genetically modified varieties (conventional breeding, organically propagated, or, if necessary, derogations are made for conventionally propagated but post-harvest untreated seed).

(2) Varieties derived from plant breeding programs with a special focus on the breeding goals or selection environments for organic farming, and organic seed propagation (product-oriented breeding for organic farming, organically propagated).

(3) Varieties derived from organic breeding programs or organic on farm breeding, which have been bred under organic farming conditions considering to the above mentioned criteria (process-oriented organic plant breeding, organically bred and propagated).

An essential element of organic farming is that it looks at agriculture as process based on a complex intertwining of agro-ecological, socio-economic and ethical principles. In addition, organic farmers are certified based on their farming process. Hence, organic farming looks at the breeding of new varieties in a holistic way. Thus, not only the variety characteristics itself but also the process of varietal development must comply with the guiding principles of organic agriculture. In this paper, we will analyze how the values of the organic sector have played a role in developing evaluation criteria and deciding what plant breeding strategies and techniques suit best for the further development of varieties that are adapted to organic farming systems. This will include the discussion on the so-called novel breeding techniques (NBT), sometimes also referred to as new plant breeding techniques (NPBT) [31], and we will discuss future requirements and challenges of organic breeding to meet the needs of this sector.

\section{The Values and Regulation Setting of Organic Agriculture}

In 1978 IFOAM was founded as the worldwide federation of organic agriculture movements, nowadays called IFOAM-Organics International, to unite all different organic agricultural initiatives and to find common ground in the norms and standards. In the 1990s, more and more conventional farmers converted to organic agriculture not only because of the organic values and societal pressure to reduce environmental risks but also as there was a growing market on local and global scale for organically produced and processed food [32]. That development finds its recognition in the forming of public regulation for organic agriculture on the European level and in addition public and private labels on national level mostly following the norms and standards that results from the organic values set by IFOAM. Other parts of the world, e.g., USA, Japan, etc., also followed with public regulations for organic agriculture [15]. 
Values are the result of a complex interplay of culture, politics, the market and the agro-ecological conditions. Values give arguments to: (i) explain the current status; (ii) give guidance to desired new developments and exclude undesired developments; (iii) pro-actively set up research and development; and (iv) evaluate and adjust standards for organic agriculture. As norms and standards are bound to time and culture, they need to be updated from time to time. Therefore, IFOAM organized a worldwide democratic process among members (close to 800 affiliates in 117 countries) over a period of two years which resulted in 2005 in reformulated values expressed in four basic principles: the principles of health, ecology, fairness and care [33]. The principle of health refers to supporting the wholeness and integrity of living systems (immunity, resilience, regeneration, sustainability), while the principle of ecology refers to the need to contribute to optimally functioning of a diversity of site specific ecological production systems and refraining from chemical-synthetic substances. The principle of fairness refers to social aspects and stresses the importance of serving equity, respect, justice and stewardship of the shared world, whereas the principle of care enhances efficiency and productivity of organic farming and processing in a precautionary and responsible manner.

\subsection{The Arguments of the Organic Sector's Ban on Genetic Engineering}

As the organic certification is based on the farming process rather than on the end products as such, it implies that also breeding as an activity within the agricultural process and is evaluated for compliance to organic values and rules [34]. The first ban on GE came from IFOAM's General Assembly in 1993 [35], followed by the European Regulation for organic agriculture in 1999 [29]. The main arguments given at that time by IFOAM were mainly related to ecological risks but also included a first notion of ethical arguments based on respect for the integrity of life, including plants [35]. The conceptualization of this argument of integrity of life was elaborated some years later [36], and further discussed in Section 2.2. Verhoog [37] further analyzed the arguments of the organic sector and summarized them in three categories: (i) environmental and health risks; (ii) socio-economic and legal aspects; and (iii) values and principles of sustainability of the organic sector.

With respect to the first category of arguments concerning environmental and health risks, the organic sector feared the unpredictability of undesired side effects such as environmental and health risks considered from the organic holistic view as inherent to the reductionist approach of GM, supported by the fact that many scientists were not agreeing on the risk-analyses and the interpretation of those data [37]. While the risk of GMO plants might have been overestimated, their claimed benefit was also exaggerated [10]. The widespread use of herbicide resistant genotypes eased the workload of conventional farmers, however, it also resulted in increased herbicide residues in feed and human food [38] and within short time their benefits are overcome by resistant weeds. Similar for Bt cotton, after wide spread use, severe yield losses were caused in India in 2016 due to resistant pink bollworm attack [39]. Giving high priority to holistic approaches, the organic sector has a different risk perception and therefore different interpretation of outcomes of risk analyses. Hence, it rather applies the precautionary principle (Principle of care) to avoid any ecological risks and therefore seeks for alternative solutions.

With respect to the second set of arguments (socio-economic aspects), the organic sector was concerned about the freedom of choice for the farmer and consumer due to contamination of GE and non-GE products as not every country has clear coexistence rules [37]. Another aspect in this category is the concern about the intellectual properties rights through patenting and the loss of independence of farmers in their choice of seeds and their ability to save their own seeds.

The third category of arguments was related to the incompatibility of GE with the principles of sustainability of the organic sector based on the holistic approach to the living nature, respecting and supporting the ability of self-regulation by ecological management and respecting the integrity of living entities, based on the four basic principles of OA as described above [36,37]. 


\subsection{Continuous Developments and the Need for Clear Evaluation Criteria}

In the early stages (end of the 1990s) of the GE development, the Dutch government accepted the exclusion of GE by the organic sector but required the Louis Bolk Institute to develop a clear and consistent framework and criteria to evaluate all at that time existing breeding techniques. This resulted in a process with many national and international workshops with organic players and reports since 1997 [40-42]. The organic sector goes a step further than from a stewardship attitude that considers natural resources at the disposal of mankind albeit managed with care in order to maintain resources for next generations. From the holistic view the organic sector embraces the partner attitude towards nature which includes that not only humans and animals but all living entities, including plants, are considered ethically relevant out of respect for the integrity of life, referring not only to an extrinsic value (usefulness for mankind) but also to a perceived intrinsic value of living organisms (worth as an living entity as such based on respect for their "otherness", dignity, wholeness and autonomy). The dignity of living organism including plants have for example been implemented as a common value in the Swiss Federal Constitution of 2002 [43]. This respect for the integrity of life has consequences in the decision making on how to manage (cultivated) plants in OA, refraining from violating the integrity of life and as a consequence cooperating with nature rather than excluding nature [36]. This respect for the integrity of life is also one of the reasons for organic agriculture to refrain from inorganic (chemical-synthetic) substances and to allow only organic substances.

To make the concept of intrinsic value of plants operational, four levels of integrity have been distinguished: (i) the level of the nature of life in general; (ii) the level of the specific nature of plant life; (iii) the level of the species-specific nature of plants; and (iv) the level of the nature of individual plants [36]. Breeding techniques can be evaluated for violating one of more levels of integrity of life.

Techniques for variation induction, selection, maintenance and propagation can be applied at three levels: plant or crop; cell or tissue (in vitro), and DNA. As organic agriculture aims to work within the realm of life while respecting the integrity of life, the techniques that go beyond the whole plant level are considered not suitable with the values of organic agriculture and thus not suitable for use in organic plant breeding programs. As the cell can be technically considered as the lowest level of self-organizing life (as the plant can be regenerated from a single cell), one could argue that it could be allowed and it is not forbidden in the organic regulation and reflects the middle position between the two other more clearly defined categories. Techniques directly engineering at DNA level go beyond the level of the self-organized life and are therefore violating the integrity of life, and more specifically the genotypic integrity e.g., when it forces natural crossing barriers [36]. Similarly, cell fusion where cell DNA and cell cytoplasm from different organisms are merged by technological means are considered as GE according to IFOAM definition of GE in the IFOAM norms [44]. On the other hand, the use of molecular markers is not excluded in organic breeding as they are diagnostic tools for plants and do not directly interfere in DNA [45]. The organic approach is aimed at the quality of the process, respecting the integrity of living entities, therefore the focus is on a holistic approach at all organization levels, and not on an approach whereby the parts are dissected in order to guide processes on a lower organization level. This approach has been very helpful for the organic sector to determine what approaches are suitable, but sometimes criticized by scientists. The criticism is that if the organic sector wants to be completely consistent, it should also exclude all varieties bred with techniques (e.g., through mutation breeding) in the 1950 to 1980 s that do not comply with the development of the IFOAM definitions [46].

With the advent of new breeding techniques and methodologies, it became clear, that the organic sector needs an agreement on transparent criteria for their evaluation. After various discussions on a national and European level the European Consortium of Organic Plant Breeding (ECO-PB), being one of the IFOAM member organizations, submitted in 2012 a position paper on the goals and values of organic plant breeding and defined various criteria for the assessment of new breeding techniques [41,42]. ECO-PB formulated the aims of organic plant breeding as follows: (1) The breeding goals shall match the respective crop species and the needs of the complete value chain of the organic 
sector (producers, processers, traders and consumers). The breeding goals shall aim at the sustainable use of natural resources and at the same time account for the dynamic equilibrium of the entire agro-ecosystem; (2) Organic plant breeding supports sustainable food security, food sovereignty, secure supply of plant products (e.g., fiber, medicine, timber), and the common welfare of society by satisfying nutritional and quality needs of animal and human beings; (3) Organic plant breeding sustains and improves the genetic diversity of our crops, and thus contributes to the promotion of agro-biodiversity; (4) Organic plant breeding makes an important contribution to the development of our crops and their adaptation to future growing conditions (e.g., climate change). The ethical criteria, criteria for breeding strategies and the socio-economic criteria are described in detail in the position paper of the European Consortium of Organic Plant Breeding (ECO-PB) [41]. The ethical criteria to respect the genome and the cell as indivisible functional entity follow the concept of respecting integrity of life, and which is also at the basis of the basic principles of OA as above described. Therefore any technical or physical invasion into the isolated cell is refrained from and plant specific crossing barriers are respected, irrespective of potential benefit risk assessments. An important point in the breeding strategy is that organic plant breeders-breeding exclusively for OA-perform all steps from crossing till selection and multiplication under organic growing conditions. On the socio economic aspects, ECO-PB is promoting free exchange of germplasm, transparency of the breeding process, open pollinated varieties instead of F1-hybrids, participatory breeding involving farmers and the value chain and a plurality of breeding initiatives to enable a more diverse and sustainable agriculture.

Organic plant breeding is a holistic approach where the process of breeding, including technical, socio-economic and ethical aspects, is equally important as the final product (cultivar) with its characteristics [47]. With new labels for organically bred varieties such as "Bioverita" in Switzerland the sector tries to communicate its values and create valorization along the value chain up to consumers (www.bioverita.org).

New sequencing approaches combined with an increase in identification of candidate genes and more precise techniques of genetic engineering will have a big impact on plant breeding, especially since the new methods like CRISPR-Cas9 are much easier and cheaper in their application than former methods [48-51]. The potential advantages of these new techniques have been widely published. However, there has been on ongoing debate in the European Union (EU) regarding how to handle novel breeding techniques like Zinc finger nucleases, oligonucleotide directed mutagenesis, cisgenesis and intragenesis, RNA-dependent DNA methylation, grafting on GM rootstock, reverse breeding, agro-infiltration and synthetic genomics with respect to commercialization of derived cultivars for several years. Until now no legally binding decision has been made by the EU if the individual techniques shall fall under present rules for genetically modified organism (GMO) legislation [52,53]. The main drivers for adopting such techniques are their technical potential and their economic advantage by speeding up breeding processes, whereas prerequisite of known genetic information and the uncertainty if final cultivars will be classified as GMO or non-GMO are hampering the utilization of these techniques [52]. In their recommendation, Lusser et al. [53] differentiated between those techniques that: (i) introduce whole genes or longer DNA fragments versus those with less than 20 base insertion; (ii) if these genes are from the same species or different species; (iii) if they are transient or stable integrated; and (iv) if the modified plant can be detected, i.e., if they can be clearly distinguished from plants derived from cross breeding or not. If only small DNA changes have been introduced (e.g., gene editing through oligonucleotide, zinc finger nucleases, TALEN or CRISPR-Cas9) or if the gene regulation is modified (e.g., RNA-dependent DNA methylation) it will not be possible to detect such changes, except if it is protected by a patent which requires traceability.

In addition, other countries such as the USA, Japan, and Australia are struggling with proper regulation. A notable difference between EU and USA regulation is that in the EU legislation on GE the process and the product of GE are considered, while in the USA only the final product is evaluated [49]. The US recently released the first products, an anti-browning mushroom and a waxy corn, genetically modified with the gene editing tool CRISPR-Cas9 for commercialization without the 
oversight of the US Department of Agriculture with the justification that these products do not contain genetic material from plant pests such as viruses or bacteria [54]. The general public's view on safety aspects of foods derived from products of new genetic engineering techniques and the process based approach in Europe are the greatest hurdle faced for definition and implementation of regulatory processes for new plant breeding technologies in Europe. Given the difficulty in conveying concepts of modern biotechnology to the general public, there is considerable potential that the public may not immediately embrace genome editing [55]. Therefore, several attempts are made to convince the organic sector about new technologies $[46,56]$ in order to reach out to the consumers. New genome editing technologies/modern biotechnology techniques have the promise to make plant breeding more efficient and precise. They create specific mutations and have the potential to generate plants that differ from the original plant at a single nucleotide position and otherwise carry no signs of the modification [49,56,57]. Although these techniques are causing off-target mutations, the expectation is that in the future the number of off-target mutations is likely to reduce due to technological advances [49]. However, off-target mutations caused by gene editing need to be compared to a mutation rate of 3.3 base substitutions per generations in Arabidopsis thaliana [58].

It is clear that scientists are aware of public concerns $[49,56,57,59]$. However, opinions of scientists on increasing the acceptability of these technologies for the public vary. Some expect that over time GE will become accepted by the organic sector [56]. Others recognize that although new biotechnologies are becoming more precise and consumer disapproval gradually reduces, techniques such as cisgenesis still is considered as unnatural by those consumers [59]. It is expected that consumers of conventional products prefer more precise novel biotechnologies over transgenesis, and that this change in attitude is not the case for consumers of organic products [57]. Hence, it is important that scientists acknowledge the pluriformity in public opinions, and that a pluriformity in science and plant breeding is equally important. This also means that in scientific debate similar space should be available for criticism of the soundness of the arguments of the organic sector to determine acceptable principles for organic breeding [45] as for the arguments of the organic sector itself [36]. Based on the principles of organic plant breeding described by the ECO-PB [41] and in the IFOAM Norms for organic production and processing in 2014 [44] any breeding technique can be evaluated against these criteria (Table 1). The first five criteria are mandatory, whereas the possibility of farm saved seed is preferred but not an exclusive criterion. For example, marker assisted selection is a diagnostic tool based on the analysis of DNA. It does not interfere physically at the genome or cell level, it does not overcome species specific crossing barriers, and does not affect breeder's privilege or farmers' right to produce farm save seed; therefore this is acceptable for the majority of organic plant breeders. In contrast, methods which technically alter the DNA or RNA by methods of genetic engineering are not considered to be compatible with organic breeding, as this violates the integrity of the genome. Likewise, cytoplast fusion is not accepted as this is based on technically forced fusions of somatic cells to overcome species specific crossing barriers in order to introduce traits such as male sterility. This violates the integrity of the cell as a functional unit.

For the organic sector this debate is of great importance at two levels. First of all, the organic sector has to define in a participatory process including all stakeholders of the organic sector clear criteria for the evaluation of new techniques for organic plant breeding. Secondly, the organic sector has to decide which cultivars derived from conventional breeding programs are acceptable for organic production as they meet the IFOAM principles as well as the expectations of the consumers. 
Table 1. Criteria for the evaluation of breeding techniques with the principles of organic plant breeding, as described by the European Consortium for Organic Plant Breeding (ECO-PB) [41] and International Federation for Organic Agriculture Movements (IFOAM) Norms of 2014 [44].

\begin{tabular}{|c|c|c|c|c|c|c|c|}
\hline Breeding Technique & $\begin{array}{l}\text { Interference on } \\
\text { Genome Level }\end{array}$ & $\begin{array}{l}\text { Interference on } \\
\text { Cell Level }\end{array}$ & $\begin{array}{c}\text { Ability of } \\
\text { Propagation Is } \\
\text { Affected }\end{array}$ & $\begin{array}{l}\text { Overcoming } \\
\text { Crossing } \\
\text { Barriers }\end{array}$ & $\begin{array}{l}\text { Breeder's } \\
\text { Privilege Is } \\
\text { Affected }\end{array}$ & $\begin{array}{c}\text { Farmers Rights } \\
\text { to Use Farm } \\
\text { Saved Seed Is } \\
\text { Affected }\end{array}$ & Tracing Possible \\
\hline Marker assisted selection & No & No & No & No & No & No & No \\
\hline Cytoplast fusion & No & Yes & Case specific & Yes & Partly & Yes & Yes \\
\hline Zinkfinger Nucleases I and II & Yes & Yes & No & No & Yes (patent) & Yes (patent) & No \\
\hline Zinkfinger Nuclease III & Yes & Yes & No & Possibly & Yes (patent) & Yes (patent) & Yes \\
\hline Cisgenetics & Yes & Yes & No & No & Yes (patent) & Yes (patent) & Case specific \\
\hline Transgenetics & Yes & Yes & Possibly & Yes & Yes (patent) & Yes (patent) & Yes \\
\hline RNA Interference (RNAi) & Yes & Yes & No & No & Yes (patent) & Yes (patent) & No \\
\hline Reverse breeding & Yes & Yes & No & No & Yes (patent) & Yes (patent) & No \\
\hline Minichromosomes & Yes & Yes & No & Yes & Yes (patent) & Yes (patent) & Yes \\
\hline
\end{tabular}


With respect to the first task to evaluate the NBT, the organic plant breeders of ECO-PB share common values expressed in the position paper and they will not apply the above mentioned techniques in their breeding programs as in their understanding this violates the integrity of the genome or the cell. The second task to define which cultivars should be allowed in OA is much more difficult and presently under discussion at IFOAM International. Here the criteria might obtain a different priority. An example is cell fusion, which is not applied by organic plant breeders, but used widely to obtain male sterile plant for hybrid seed production in brassica vegetables. Some private labels in Germany have already banned cultivars based on cell fusion for OA, due to the fact that the integrity of life and more specifically the genotypic integrity is violated and species specific crossing borders are overcome. In order to have a well-informed discussion the different breeding methods have been described indicating their applications, potentials and ethical issues [42]. As the application of some of the novel genetic engineering techniques are not detectable, the organic sector is very concerned that they might be released without labeling. In that case, the organic sector will no longer have the freedom of informed choice. Therefore, there is a strong lobbying of IFOAM for disclosure of the breeding methods, which is presently only given if the techniques fall under the GE regulation. Transparency and freedom of choice for farmers and consumers as well as a plurality of breeding strategies will allow co-existence of GM and non-GM food chains, and will be beneficial to pluriform societies (e.g., [1-3]). Having experienced the impact of coexistence of GE on OA [60], and the disappearance of non-GE cotton seed in India within only 10 years [61], it is important to take measures in advance that different farming systems can co-exist.

In the USA, the National Organic Standards Board has decided to update the organic standards to exclude cultivars and derived organic products developed with new generation genetic engineering end gene editing techniques [62]. In Europe, a position paper of the IFOAM EU GROUP [63] urges that cultivars derived from NBT which engineer living organisms in the cell and/or nucleus through technical, chemical or biotechnological intervention shall be defined as GE and be subject to a risk assessment and if authorized for release be subject to the mandatory traceability and labeling requirements that apply to other GE techniques. This transparency is important to ensure organic farmers and customers free choice of non-GE seed and food, respectively. At the international level, the IFOAM has set up working groups on the definition of GE and the criteria for the evaluation of NBT to be discussed among the organic movement and IFOAM's members at the next general assembly in 2017.

\section{Developing Alternative Breeding Concepts}

What modern breeding techniques suit the organic sector? With the framework described in the above section it is possible to evaluate what breeding methods are appropriate and in which direction to search for good alternatives as a consequences of rejecting certain breeding techniques. The organic sector would set itself back when it does not challenge itself to seek for alternative innovations. The organic sector has dealt with such challenges before when it decided to refrain from chemical-synthetic pesticides and herbicides which implied learning how to enhance and manage biodiversity to build up agro-eco resilience and thus lowering the pest and disease pressure [25]. Refraining from synthetic fertilizer resulted in improved organic fertilizer management like composting to improve soil fertility. In the same sense, we can argue that refraining from GE is not a disadvantage but may stimulate efforts to develop innovative suitable approaches to breed for adaptive, flexible and nutritious varieties to combine plant robustness with food quality.

Does the critical evaluation of breeding techniques imply a completely new variety assortment? This is not the case; the degree of overlap between varieties suitable for conventional and/or organic farming systems depends on the crop requirements and the applied breeding techniques. In some specific crops, the problem to find suitable varieties that can perform well without high levels of mineral fertilizers and chemical-synthetic fungicides, herbicides and pesticides is larger than for other crops. For several crops like maize [64] and wheat [65] it has been shown that direct selection under the target 
farming system was essential to reach maximum breeding gains for low-input and organic farming. Cultivars for OA also need to have high weed competition or tolerance, high level of tolerance against soil and seed borne diseases and especially high requirements for shelf-life, as synthetic conservatives are not allowed. There is not only a need for varieties that fit in an organic system with good yield potential and nutritional quality but also that allow the organic systems to work, meaning that the resilience of the whole farming system is supported and enhanced. Luby et al. [66] argue that the organic sector has not yet reached its full potential until growers have access to regional adapted and organically bred varieties that balance yield with nutritional quality. In addition, organic plant breeding aims to contribute to new more sustainable production systems through breeding for more diversity within cultivars, development of composite cross populations of cereals presently under test marketing in the EU, or breeding for mixed cropping systems and for improved resilience due to enhanced plant-microbe symbiosis.

\subsection{Future Direction for Crop Improvement in Organic Agriculture}

Values are not only aiming at excluding unwanted developments but also to give direction to desired developments in breeding. The IFOAM basic principles-the principles of health, ecology, fairness and care-are very helpful to support the development of appropriate breeding approaches [44]. Besides, breeding is not only a technical activity but also a socio-economic and legal construction. This requires creativity to find suitable organizational and business models to finance breeding for a diverse assortment adapted to various regions and various crops, including small crops. This is particularly reflected in the principles of fairness and care.

The Principle of Health in organic plant breeding is about serving the wholeness and integrity of living systems (including society) at various levels (immunity, resilience, regeneration, sustainability). The implication for breeding is that varieties need to be robust and dynamic, weed suppressive and disease tolerant, able to benefit from interactions with beneficial soil organisms, and to reproduce themselves and to produce high quality, nutritious food.

The Principle of Ecology in organic plant breeding is about contributing to optimally functioning of a diversity of site specific ecological production systems. This means that breeding needs to develop multilevel approaches, such as decentralized breeding for regional adaptability and enhancing genetic diversity and adapt the seed to the environment instead of the environment to the seed.

The Principle of Fairness in organic plant breeding is about serving equity, respect, justice and stewardship of the shared world. It implies the need to develop new socio-economic structures in breeding to ensure free access to genetic resources, no patents of life, breeding approaches that involve all value chain actors, equal benefit sharing among chain partners, and maintenance and accessibility of diversity for future generations.

The Principle of Care in organic plant breeding is about enhancing efficiency and productivity in a precautionary and responsible manner. We argue that there is plenty of unexplored (and forgotten) knowledge for new multifaceted breeding strategies! It means that organic breeding refrains from breeding techniques that interfere directly at DNA, including cell fusion and mutation breeding, and stimulates transparent and participatory/collaborative processes.

Varieties that meet these four criteria can be called organic varieties [67]. The question is how to organize and finance breeding for so-called organic varieties? The past 10-30 years various initiatives at various levels (e.g., farmers, breeders, researchers, and wholesalers), particularly in Europe [68] and North America [69], have been set up to develop approaches that fit organic breeding better. Next to the development of organic breeding companies in the past 30 years, we can identify two novel approaches including combinations of both.

- Chain-based breeding: The whole chain is involved, either contributing in cash, or in kind. For successful chain-based breeding, it is important that all chain players have economic benefit, directly, or indirectly. An example is the Dutch potato breeding system based on collaborations 
between commercial breeding companies and various potato growers involved in the early selection process [70].

- Community-based breeding: A group of people, together forming a community, sharing an idea or vision. For successful community-based breeding, it is important that the community has a clear common vision and goal. An example can be farmer-based breeding: a group of farmers working together (Kultursaat in Germany). A group of farmers and bakers can also form a community (Resources de Semence Paysanne in France).

\subsection{How to Stimulate Organic Variety Development?}

In order to make such initiatives successful and to meet the needs of a diversified organic market, it is important to take the local/regional agro-ecological and socio-economic context into account. A set of key-elements has been developed to understand how to increase the chances of success [67]. One important element is that policy makers can play an important role to increase the window of opportunity for such initiatives. At the moment many of these initiatives are set up at the niche level. Policy and law influence the possibility of such small initiatives to grow, although in different ways, as, for example policy and law on organic seeds in the EU and US are different [71]. Good interaction with market players that are part of the mainstream agriculture can increase the longevity of such initiatives or even influence and reshape conventional breeding and agriculture. According to Geels and Schot [72] there are various transition pathways. The success of these transitions depend on a number of factors: (1) entrepreneurial activities; (2) knowledge development; (3) knowledge exchange; (4) guidance of the search; (5) formation of markets; (6) mobilization of resources; and (7) counteracting resistance to change [73]. The past 30 years, particularly entrepreneurial activities, knowledge development, knowledge exchange and formation of markets have increased clearly. Counteracting resistance to change has reduced as the number of conventional seed companies selling organically produced seed continuous to grow. For example, in the Netherlands, 42 companies are producing organic seed [74]. As the organic sector is growing and organic seed production is growing at a fast rate, it is plausible breeding for organic and organic breeding gradually can become more profitable in the future. Some of the organic breeding initiatives such as the community-based initiative Bingenheimer Saatgut in Germany started at the niche level and is gradually becoming a normal market player.

\subsection{Institutionalisation of Organic Plant Breeding}

Successful innovations cannot always be planned [75,76]. Some innovations are the result of institutionalized processes, whereas other innovations emerge spontaneously [76]. Perhaps this needs to be considered an advantage: to increase genetic diversity and crop diversity, it is crucial to have diversity at the socio-economic level. The more different types of breeding initiatives develop, the more crop diversity will be maintained.

Beneficial institutionalizing processes of organic plant breeding are developing a clear set of standards. For example, IFOAM has adopted standards for organic seed production within their basic standards, and drafted standards for organic plant breeding in collaboration with ECO-PB [41]. Since 2004, the EU has stipulated in their regulation that OA requires organically produced seeds, and requires request for derogation for the use of non-organic seeds (see www.organicxseeds.com). However, institutionalization may mean increasing efficiency, but may result in decreasing diversity. Therefore, a careful balance between institutionalization and the spontaneous development of new initiatives need to be taken care of. At the moment some conventional companies (potato, vegetables, cereals and fodder crops) become more interested in the (conventional) sustainable or low-input and organic market sector, and see opportunities to serve both markets by slightly reshaping their breeding program [30,77].

There is also recognition at scientific level: In 2005 the first professor of organic plant breeding was appointed at Wageningen University, and in 2013 at Kassel University, and five planned in the 
USA [78]. Research programs for organic plant breeding activities are running in many countries [47], and at the European level the Horizon 2020 program calls for projects on organic seed and breeding.

\section{Discussion}

In this paper, we have described the development of a set of guiding principles for the evaluation of breeding techniques by the organic sector over time. As there are differences in values between organic and conventional agriculture, we first described the basic principles of OA. Bringing such underlying values forward is a choice of the international organic movement represented by IFOAM and allows the organic movement to distinguish itself from other approaches in sustainability. Organic products serve consumers who share the values of OA. In that perspective, and given the self-chosen principles of OA, we will discuss the consequences of such choices for the future of organic seed and breeding.

It is often argued that in order to meet the food demand of a growing population, all available tools need to be applied. Over the past 15 years, several new techniques have been developed and are being implemented to facilitate breeding of improved crop varieties. Compared with traditional breeding, these techniques are expected to increase the precision of making changes in the genomes and thereby reduce the time and effort that is needed to produce varieties with new traits that meet new requirements [31] or with reintroduced traits that have been lost during domestication [57]. It is expected that the number of off-target mutations will reduce in the future [49]. While the first generation of GE-plants focused mainly on herbicide resistance and insect resistance, the genetic and epigenetic knowledge has dramatically increased in recent years. The genome sequencing of hundreds of genotypes and the mining of allele diversity in major crops and populations of landraces and wild relatives allow the genetic engineering of a larger array of traits [79]. For example, for more sustainable potato cultivation, certain elite potato varieties can be equipped with various combinations of resistance genes to the prevalent pathotypes of Phytophthora infestans by cisgenesis. However, combining resistance genes from different wild sources is also possible with traditional breeding in combination with the use of molecular markers but will take longer [27]. Another example is that, by using genome-editing tools that enable the production of very precise changes, new disease resistances are expected to be created by switching off susceptibility genes, without affecting plant fitness [31].

Most frequent arguments of the organic sector against GE and related techniques are focused on the consequences of GE-techniques: on the environment, human health and the social position of the farmer. These arguments seem not always the most convincing arguments as risk perception is bound to cultural and socio-economic aspects that can change over time [2,4]. In other words, because of different risk perceptions, arguments of the organic sector may not be convincing for those that do not adhere the values of organic agriculture. Verhoog [37] considers the arguments based on the organic principles as more specific and more credible arguments. Awareness among scientists and policy makers has increased that it is important to acknowledge a pluriformity in public opinion and that scientists need to be open to concerns of the public $[49,57,59,80]$.

We have argued that plant breeding is not only a technical activity to develop new cultivars, but that it is also about the organization of social environment for these activities, including law, policy, culture (values) and the market. There is a complex interaction between new innovations and the development of society [76]. Hence, breeding techniques are not neutral tools, but result from and represent paradigms (e.g., views on the organization of food production). Which breeding approaches and breeding techniques are most suitable for which farming systems depend on a complex of agro-ecological, socio-economic and cultural factors. Hence, worldwide food security is not only a matter of increasing productivity but is also shaped by a complex of socio-economic, cultural and political factors such as food sovereignty, access to land, seed and water, empowerment of farmers and rural populations and food distribution to non-farming populations in cities. Given the pluriformity in agro-ecological and societal contexts, we envisage breeding for organic agriculture to be organized in various ways to be able to meet this diversity in agro-ecological and societal contexts worldwide. 
Thus far, only a few breeding initiatives are conducted specifically for and in OA ("organic plant breeding") [30,67]. However, their market is expected to grow rapidly in the future. Here we highlight three main directions to realize the organic breeding objectives: (1) cooperation with conventional breeding companies; (2) the development of technical innovative breeding strategies based on the principles of organic agriculture; and (3) of innovative organizational strategies such as participatory and collaborative approaches with farmers and other chain players. These three directions will be discussed below.

The first direction, cooperation with conventional breeding companies, is gradually becoming more realistic as the organic sector is growing and provides an interesting market for conventional breeding companies to address. IFOAM estimates the potential of the total market share around $20 \%$ when the sector adopts continuous further improvement of its farming strategies [15]. Already a large number of seed companies have proven interest in propagation of part of their conventional cultivar assortment organically and the next step is reshaping their breeding program for traits that are of importance for organic farming systems. Sooner or later, traits such as improved nutrient efficiency and improved root systems will also contribute to the sustainability development in conventional agriculture. However, currently only a few conventional breeding companies integrate the needs of organic farming into their program ("breeding for organic agriculture") [30]. Osman et al. [77] have described these interactions in more detail for the development of organic wheat variety profiles. It is an example of how the organic food chains can cooperate with conventional breeders.

However, collaboration with conventional breeding companies should not be the only strategy to achieve better adapted cultivars for OA. We also need to consider there has been a fast consolidation and monopolization of the seed market, with three global companies controlling over $50 \%$ of the market [81], replacing local family owned and public breeding activities. As a result, we have lost not only the genetic diversity of numerous local varieties and landraces [82], but also dramatically reduced the number of crop species used for our food production. This is important, as crop diversification has been identified as key for adaptation to environmental change [83]. This leads us to discuss the second and the third direction.

The second direction is to further develop technical innovative breeding strategies for OA. Several studies have demonstrated that the highest breeding gain for OA could only be achieved when selecting under the target conditions of organic farming $[64,84]$. This either requires breeding companies to include organic selection fields in the program [85] or involve organic farmers in the selection process [86]. Besides, the potential of within-crop diversity, such as composite cross populations in cereals and mixtures of modern cultivars [87], and breeding for mixed cropping systems [88] are being explored to enhance yield stability and the resilience of organic agro-systems.

The third direction is to improve the organizational aspects of breeding for OA, e.g., to further develop participatory plant breeding and collaborative breeding involving farmers and other chain actors. Such can be powerful and cost efficient approaches for developing a diverse assortment of locally adapted and open pollinated cultivars for a large range of crops $[86,89,90]$, with the possibility to achieve equal or higher yield compared to modern high yielding F1 hybrids due to optimized use of local/regional adaptation [91]. An example is the case of open pollinated sweet corn development in USA [92]. The role of farmer seed networks in conservation of agro-biodiversity and the development of new genetic diversity and varieties in that way contributing to local food security was highlighted in various studies across the world, including developed and developing countries [93-95]. However, to upscale such participatory and collaborative breeding, additional new organizational approaches are needed that focus on the financial aspects of breeding and that involve other chain players and the consumers in plant breeding [67]. In Europe and USA several initiatives are exploring new concepts of open source seed (considering seed as a common good) as alternatives to the monopolization of the seed market, but requires new concepts of financing to be developed [96]. In recent years, several traders, retailers and supermarkets are actively involved in supporting organic breeding. Following the IFOAM principles, various organic breeding initiatives consider it also important to involve consumers 
to raise awareness on fair seed developments and their role as consumers [96]. For consumers not only price, taste and quality is important, but also the management of biodiversity. The actual price consumes are willing to pay for products that foster biodiversity management depends on how they are approached in shops [97]. It is a direction that requires further exploration. Such approach is very different from current developments in conventional breeding on reshaping licensing of patents that are only accessible for large breeding companies [98].

To summarize, the organic sector needs to further develop various breeding approaches that fit with the principles of the IFOAM. This will also require political dialog and public intervention in agricultural research to support new concepts of organic plant breeding in which the whole value chain up to the final consumers are included $[99,100]$. To facilitate such developments, interdisciplinary research is needed to integrate knowledge from the technical and social sciences [7]. A pluriformity in breeding approaches suited for OA considering different agro-ecological and socio-economic contexts will allow breeding for local adaptation and niche markets. This will contribute to the maintenance of diversity of our crop plants and, thus, lower risks of total crop failure due to extreme weather events expected due to climate change.

Acknowledgments: Authors would like to thank the anonymous reviewers and the editor for the valuable comments to improve the manuscript. The authors gratefully acknowledge funding for writing this paper from the Program Groene Veredeling financed by the Ministry of Economic Affairs in The Netherlands, and the EU project DIVERSIFOOD (Embedding crop diversity and networking for local high quality food systems). This project has received funding from the European Union's H2020 Programme under grant agreement No. 633571 for the period 2015-2019.

Author Contributions: Authors work in the field of organic plant breeding. First author is board member of $\mathrm{ECO}-\mathrm{PB}$ and second author is the current chair of ECO-PB. All three authors have contributed equally to the writing of this review.

Conflicts of Interest: The authors declare no conflict of interest.

\section{References}

1. Bawden, R. The community challenge: The learning response. In Social Learning Systems and Communities of Practice; Blackmore, C., Ed.; Springer: London, UK, 2010; pp. 39-56.

2. Douglas, M. How Institutions Think; Routledge \& Kegan Paul: London, UK, 1986.

3. Nuijten, E.; van Bueren, E.L. Towards a more community oriented and chain-based breeding. Understanding underlying principles for successful new models. In Strategies for Organic and Low-Input Integrated Breeding and Management, Book of Abstracts, Proceedings of the Diversity Strategies for Organic and Low Input Agricultures and Their Food System, Nantes, France, 7-9 July 2014; Organic Eprints: Tjele, Denmark, 2014; pp. 19-20.

4. Verweij, M. Whose behaviour is affected by international anarchy? In Cultural Theory as Political Science; Thompson, M., Grendstad, G., Selle, P., Eds.; Routledge: London, UK; New York, NY, USA, 1999; pp. 27-42.

5. Maat, H. Science cultivating practice: A history of agricultural science in The Netherlands and its colonies 1863-1986. In The International Library of Environmental, Agricultural and Food Ethics Series 1; Springer: Dutch, The Netherlands, 2001.

6. Pretty, J.N. Participatory learning for sustainable agriculture. World Dev. 1995, 23, 1247-1263. [CrossRef]

7. Nuijten, E. Combining research styles of the natural and social sciences in agricultural research. NJAS J. Life Sci. 2011, 57, 197-205. [CrossRef]

8. Hisschemöller, M.; Hoppe, R. Coping with intractable controversies: The case for problem structuring in policy design and analysis. Knowl. Policy 1995, 8, 40-60. [CrossRef]

9. Ceccarelli, S. GM Crops, Organic Agriculture and Breeding for Sustainability. Sustainability 2014, 6, 4273-4286. [CrossRef]

10. Jacobsen, S.; Sørensen, M.; Pedersen, S.M.; Weiner, J. Feeding the world: Genetically modified crops versus agricultural biodiversity. Agron. Sustain. Dev. 2013, 33, 651-652. [CrossRef]

11. Lucht, J.M. Public acceptance of plant biotechnology and GM crops. Viruses 2015, 7, 4254-4281. [CrossRef] [PubMed] 
12. Fraser, E.; Legwegoh, A.; Krishna, K.; CoDyre, M.; Dias, G.; Hazen, S.; Johnson, R.; Martin, R.; Ohberg, L.; Sethuratnam, S.; et al. Biotechnology or organic? Extensive or intensive? Global or local? A critical review of potential pathways to resolve the global food crisis. Trends Food Sci. Technol. 2016, 48, 78-87. [CrossRef]

13. International Federation of Organic Agriculture Movements (IFOAM). Principles of Organic Agriculture Preamble; IFOAM Organics International: Bonn, Germany, 2016. Available online: http:/ /www.ifoam.bio/ en/organic-landmarks/principles-organic-agriculture (accessed on 13 November 2016).

14. Arbenz, M.; Gould, D.; Stopes, C. Organic 3.0 for Truly Sustainable Farming and Consumption; Discussion Paper; IFOAM Organics International: Bonn, Germany, 2015.

15. Willer, H.; Lernoud, J. (Eds.) The World of Organic Agriculture. Statistics an Emerging Trends 2016; Research Institute of Organic Agriculture (FiBL): Frick, Switzerland; IFOAM Organics International: Bonn, Germany, 2016.

16. Brandt, K.; Leifert, C.; Sanderson, R.; Seal, C.J. Agroecosystem Management and Nutritional Quality of Plant Foods: The Case of Organic Fruits and Vegetables. Crit. Rev. Plant Sci. 2011, 30, 177-197. [CrossRef]

17. Crowder, D.W.; Reganold, J.P. Financial competitiveness of organic agriculture on a global scale. Proc. Natl. Acad. Sci. USA 2015, 112, 7611-7616. [CrossRef] [PubMed]

18. Reganold, J.P.; Wachter, J.M. Organic agriculture in the twenty-first century. Nat. Plants 2016, 2, 15221. [CrossRef] [PubMed]

19. De Ponti, T.; Rijk, B.; van Ittersum, M.K. The crop yield gap between organic and conventional agriculture. Agric. Syst. 2012, 108, 1-9. [CrossRef]

20. Kniss, A.R.; Savage, S.D.; Jabbour, R. Corrections: Commercial crop yields reveal strengths and weaknesses for organic agriculture in the United States. PLOS ONE 2016, 11, e0165851. [CrossRef] [PubMed]

21. Seufert, V.L.; Ramankutty, N.; Foley, J.A. Comparing the yields of organic and conventional agriculture. Nature 2012, 485, 229-232. [CrossRef] [PubMed]

22. Niggli, U. Sustainability of organic food production: Challenges and innovations. Proc. Nutr. Soc. 2015, 74, 83-88. [CrossRef] [PubMed]

23. Ponisio, L.C.; M'Gonigle, L.K.; Mace, K.C.; Palomino, J.; de Valpine, P.; Kremen, C. Diversification practices reduce organic to conventional yield gap. Proc. Biol. Sci. 2015, 282, 20141396. [CrossRef] [PubMed]

24. Przystalski, M.; Osman, A.; Thiemt, E.M.; Rolland, B.; Ericson, L.; Østergård, H.; Levy, L.; Wolfe, M.; Büchse, A.; Piepho, H.-P.; et al. Comparing the performance of cereal varieties in organic and non-organic cropping systems in different European countries. Euphytica 2008, 163, 417-433. [CrossRef]

25. Van Bruggen, A.H.C.; Finckh, M.R. Plant Diseases and Management Approaches in Organic Farming Systems. Annu. Rev. Phytopathol. 2016, 54, 25-54. [CrossRef] [PubMed]

26. Van Bueren, E.L.; Jones, S.S.; Tamm, L.; Murphy, K.M.; Myers, J.R.; Leifert, C.; Messmer, M.M. The need to breed crop varieties suitable for organic farming, using wheat, tomato and broccoli as examples: A review. NJAS Wagening. J. Life Sci. 2011, 58, 193-205. [CrossRef]

27. Van Bueren, E.L.; Engelen, C.; Hutten, R. Participatory potato breeding model involving organic farmers and commercial breeding companies in The Netherlands. In Proceedings of the Organic Seed Growers Conference, Corvallis, OR, USA, 30 January-1 February 2014; Hubbard, K., Ed.; Organic Seed Alliance: Port Townsend, WA, USA, 2014; pp. 69-73.

28. Scholten, O.E.; van Heusden, A.W.; Khrustaleva, L.I.; Burger-Meijer, K.; Mank, R.A.; Antonise, R.G.C.; Harrewijn, J.L.; van Haecke, W.; Oost, E.H.; Peters, R.J.; et al. The long and winding road leading to the successful introgression of downy mildew resistance into onion. Euphytica 2007, 156, 345-353. [CrossRef]

29. European Commission. Council Regulation (EC) No 834/2007 of 28 June 2007 on Organic Production and Labeling of Organic Products and Repealing Regulation (EEC) No 2092/91. Available online: http:/ /eur-lex.europa.eu/LexUriServ/LexUriServ.do?uri=OJ:L:2007:189:0001:0023:EN:PDF (accessed on 21 December 2016).

30. Wolfe, M.S.; Baresel, J.P.; Desclaux, D.; Goldringer, I.; Hoad, S.; Kovacs, G.; Löschenberger, F.; Miedaner, T.; Østergård, H.; van Bueren, E.L. Developments in breeding cereals for organic agriculture. Euphytica 2008, 163, 323-346. [CrossRef]

31. Schaart, J.G.; van de Wiel, C.C.M.; Lotz, L.A.P.; Smulders, M.J.M. Opportunities for products of new plant breeding techniques. Trends Plant Sci. 2016, 21, 438-449. [CrossRef] [PubMed] 
32. Alrøe, H.; Noe, E. What makes organic agriculture move: Protest, meaning or market?: A polyocular approach to the dynamics and governance of organic agriculture. Int. J. Agric. Resour. Gov. Ecol. 2008, 7, 5-22. [CrossRef]

33. Lukkitholt, L.W.M. Principles of organic agriculture as formulated by the International Federation of Organic Agriculture Movements. NJAS Wagening. J. Life Sci. 2007, 54, 347-360.

34. Van Bueren, E.L.; Verhoog, H.; Tiemens-Hulscher, M.; Struik, P.C.; Haring, M.A. Organic agriculture requires process rather than product evaluation of novel breeding techniques. NJAS Wagening. J. Life Sci. 2007, 54, 401-412.

35. Bullard, L.; Geier, B.; Koechlin, F.; Leskin, D.; Meister, I.; Verhagen, N. Organic agriculture and genetic engineering. Ecol. Farming Mag. 1994, 8, 25-26.

36. Van Bueren, E.L.; Struik, P.C.; Tiemens-Hulscher, M.; Jacobsen, E. The concepts of intrinsic value and integrity of plants in organic plant breeding and propagation. Crop Sci. 2003, 43, 1922-1929. [CrossRef]

37. Verhoog, H. Organic agriculture versus genetic engineering. NJAS Wagening. J. Life Sci. 2007, 54, 387-400. [CrossRef]

38. Samsel, A.; Seneff, S. Glyphosate's Suppression of Cytochrome P450 Enzymes and Amino Acid Biosynthesis by the Gut Microbiome: Pathways to Modern Diseases. Entropy 2013, 15, 1416-1463. [CrossRef]

39. Fabrick, J.A.; Unnithan, G.C.; Yelich, A.J.; Ben DeGain, B.; Masson, L.; Zhang, J.; Carrière, Y.; Tabashnik, B.E. Multi-Toxin Resistance Enables Pink Bollworm Survival on Pyramided Bt Cotton. Sci. Rep. 2015, 5, 16554. [CrossRef] [PubMed]

40. Van Bueren, E.L.; Hulscher, M.; Jongerden, J.; Ruivenkamp, G.T.P.; Haring, M.; Van Mansvelt, J.D.; Den Nijs, A.M.P. Sustainable Organic Plant Breeding-A Vision, Choices, Consequences and Steps; Louis Bolk Institute: Driebergen, The Netherlands, 1999.

41. European Consortium for Organic Plant Breeding (ECO-PB). Position Paper on Organic Plant Breeding; ECO-PB: Frankfurt, Germany, 2012.

42. Messmer, M.; Wilbois, K.-P.; Baier, C.; Schäfer, F.; Arncken, C.; Drexler, D.; Hildermann, I. Plant Breeding Techniques-An Assessment for Organic Farming; Dossier No. 2; FiBL: Frick, Switzerland, 2015.

43. Bundesverfassung der Schweizerischen Eidgenossenschaft. Available online: https://www.admin.ch/opc/ de/classified-compilation/19995395/200112020000/101.pdf (accessed on 21 December 2016).

44. International Federation of Organic Agriculture Movements (IFOAM). The IFOAM Norms; IFOAM: Bonn, Germany, 2014.

45. Van Bueren, E.L.; Østergård, H.; De Vriend, H.; Backes, G. Role of molecular markers and marker assisted selection in breeding for organic and low-input agriculture. Euphytica 2010, 175, 51-64. [CrossRef]

46. Ammann, K. Integrated farming: Why organic farmers should use transgenic crops. New Biotechnol. 2008, 25, 101-107. [CrossRef] [PubMed]

47. Crespo-Herrera, L.A.; Ortiz, R. Plant breeding for organic agriculture: Something new? Agric. Food Secur. 2015, 4, 25. [CrossRef]

48. Schaeffer, S.M.; Nakata, P.A. CRISPR/Cas9-mediated genome editing and gene replacement in plants: Transitioning from lab to field. Plant Sci. 2015, 240, 130-142. [CrossRef] [PubMed]

49. Araki, M.; Ishii, T. Towards social acceptance of plant breeding by genome editing. Trends Plant Sci. 2015, 20, 145-149. [CrossRef] [PubMed]

50. Barabaschi, D.; Tondellia, A.; Desiderioa, F.; Volanteb, A.; Vaccinoc, P.; Valèb, G.; Cattivellia, L. Next generation breeding. Plant Sci. 2016, 242, 3-13. [CrossRef] [PubMed]

51. Schiml, S.; Puchta, H. Revolutionizing plant biology: Multiple ways of genome engineering by CRISPR/Cas. Plant Methods 2016, 12, 8. [CrossRef] [PubMed]

52. Lusser, M.; Parisi, C.; Plan, D.; Rodríguez-Cerezo, E. New Plant Breeding Techniques State-of-the-Art and Prospects for Commercial Development; European Commission, Joint Research Centre: Luxembourg, 2011.

53. Lusser, M.; Parisi, C.; Plan, D.; Rodríguez-Cerezo, E. Deployment of new biotechnologies in plant breeding. Nat. Biotechnol. 2012, 30, 231-239. [CrossRef] [PubMed]

54. Waltz, E. CRISPR-edited crops free to enter market, skip regulation. Nat. Biotechnol. 2016, 34, 582. [CrossRef] [PubMed]

55. Wolt, J.D.; Wang, K.; Yang, B. The Regulatory Status of Genome-edited Crops. Plant Biotechnol. J. 2016, 14, 510-518. [CrossRef] [PubMed] 
56. Ryffel, G.U. Orgenic plants: Gene-manipulated plants compatible with organic farming. Biotechnol. J. 2012, 7, 1328-1331. [CrossRef] [PubMed]

57. Andersen, M.M.; Landes, X.; Xiang, W.; Anyshchenko, A.; Falhof, J.; Østerberg, J.T.; Olsen, L.I.; Edenbrandt, A.K.; Vedel, S.Z.; Thorsen, B.J.; et al. Feasibility of new breeding techniques for organic farming. Trends Plant Sci. 2015, 20, 426-434. [CrossRef] [PubMed]

58. Ossowski, S.; Schneeberger, K.; Lucas-Lledo, J.I.; Warthmann, N.; Clark, R.M.; Shaw, R.G.; Weigel, D.; Lynch, M. The rate and molecular spectrum of spontaneaous mutations in Arabidopsis thaliana. Science 2016, 327, 92-94. [CrossRef] [PubMed]

59. Palmgren, M.G.; Edenbrandt, A.K.; Vedel, S.E.; Andersen, M.M.; Landes, X.; Østerberg, J.T.; Falhof, J.; Olsen, L.I.; Christensen, S.B.; Sandøe, P.; et al. Are we ready for back-to-nature crop breeding? Trends Plant Sci. 2015, 20, 155-164. [CrossRef] [PubMed]

60. Bertheau, Y. (Ed.) Genetically Modified and Non-Genetically Modified Food Supply Chains: Co-Existence and Traceability; Wiley Blackwell: Oxford, UK, 2012.

61. Gutierrez, A.P.; Ponti, L.; Herren, H.R.; Baumgärtner, J.; Kenmore, P.E. Deconstructing Indian cotton: Weather, yields, and suicides. Environ. Sci. Eur. 2015, 27, 12-28. [CrossRef]

62. Friends of the Earth. Organic Standards Will Exclude Next Generation of GMOs. 2016. Available online: http://www.foe.org/news/news-releases/2016-11-organic-standards-will-exclude-nextgeneration-of-gmos (accessed on 30 November 2016).

63. IFOAM EU GROUP. New Plant Breeding Techniques-Position Paper. 2015. Available online: http://www.ifoam-eu.org/sites/default/files/ifoameu_policy_npbts_position_final_20151210.pdf (accessed on 21 December 2016).

64. Messmer, M.M.; Burger, H.; Schmidt, W.; Geiger, H.H. Importance of Appropriate Selection Environments for Breeding Maize Adapted to Organic Farming Systems. In Tagungsband der 60. Jahrestagung der Vereinigung der Pflanzenzüchter und Saatgutkaufleute Österreichs; Raumberg-Gumpenstein: Irdning, Austria, 2010; pp. 49-52.

65. Reid, T.A.; Yang, R.C.; Salmon, D.F.; Navabi, A.; Spaner, D. Realized gains from selection for spring wheat grain yield are different in conventional and organically managed systems. Euphytica 2011, 177, 253-266. [CrossRef]

66. Luby, C.H.; Lyon, A.H.; Shelton, A.C. A New Generation of Plant Breeders Discovers Fertile Ground in Organic Agriculture. Sustainability 2013, 5, 2722-2726. [CrossRef]

67. Nuijten, E.; van Bueren, E.L. Key elements for collaborative breeding models for organic markets in Europe. In Proceedings of the Organic Seed Growers Conference, Corvallis, OR, USA, 4-6 February 2016; Davis, K., Ed.; Organic Seed Alliance: Port Townsend, WA, USA, 2016; pp. 47-52.

68. Chable, V.; Conseil, M.; Serpolay, E.; le Lagadec, F. Organic varieties for cauliflowers and cabbages in Brittany: From genetic resources to participatory plant breeding. Euphytica 2008, 164, 521-529. [CrossRef]

69. Renaud, E.C.M.; van Bueren, E.L.; Jiggins, J. The Process of Interpreting and Implementing Organic Seed Regulation in the United States. Org. Agric. 2014, 4, 25-42. [CrossRef]

70. Almekinders, C.J.M.; Mertens, L.; van Loon, J.P.; van Bueren, E.L. Potato breeding in The Netherlands: A successful participatory model with collaboration between farmers and commercial breeders. Food Secur. 2014, 6, 515-524. [CrossRef]

71. Renaud, E.C.M.; van Bueren, E.L.; Jiggins, J. The meta-governance of organic seed regulation in the USA, European Union and Mexico. Int. J. Agric. Resour. Gov. Ecol. 2016, 12, 262-291. [CrossRef]

72. Geels, F.W.; Schot, J. Typology of sociotechnical transition pathways. Res. Policy 2007, 36, 399-417. [CrossRef]

73. Hekkert, M.P.; Suurs, R.A.A.; Negro, S.O.; Kuhlmann, S.; Smits, R.E. Functions of innovation systems: A new approach for analysing technological change. Technol. Forecast. Soc. Chang. 2007, 74, 413-432. [CrossRef]

74. Biodatabase. Database for Organic Starting Material in The Netherlands. 2016. Available online: http://www.biodatabase.nl/en/ (accessed on 17 November 2016).

75. Batterbury, S. Planners or performers? Reflections on indigenous dryland farming in northern Burkina Faso. Agric. Hum. Values 1996, 13, 12-22. [CrossRef]

76. Nuijten, E.; Temudo, M.; Richards, P.; Okry, F.; Teeken, B.; Mokuwa, A.; Struik, P.C. Towards a new approach for understanding interactions of Technology with Environment and Society in small-scale rice farming. In Realizing Africa's Rice Promise; Wopereis, M.C.S., Johnson, D.E., Ahmadi, N., Tollens, E., Jalloh, A., Eds.; CABI Publishing: Wallingford, UK, 2013; pp. 355-366. 
77. Osman, A.M.; Almekinders, C.J.M.; Struik, P.C.; van Bueren, E.L. Adapting spring wheat breeding to the needs of the organic sector. NJAS Wagening. J. Life Sci. 2016, 76, 55-63. [CrossRef]

78. Kolwake, J. Clif Bar Spearheads $\$ 10$ Million Investment to Fund Five Endowed Chairs Focused on Organic Agricultural Research. 2016. Available online: http://www.clifbar.com/newsroom/clif-bar-spearheads-10million-investment-to-fund-five-endowed-chairs-focused-on-organic-agricultural-research (accessed on 9 September 2016).

79. Cardi, T. Cisgenesis and genome editing: Combining concepts and efforts for a smarter use of genetic resources in crop breeding. Plant Breed. 2016, 135, 139-147. [CrossRef]

80. COGEM (Commission on Genetic Modificatio). Towards an Integrated Framework for the Assessment of Social and Ethical Issues in Modern Biotechnology; COGEM Advisory Report to the State Secretary for Housing, Planning and the Environment (CGM/030618-02); COGEM: Bilthoven, The Netherlands, 2003.

81. Howard, P.H. Visualizing Consolidation in the Global Seed Industry: 1996-2008. Sustainability 2009, 1, 1266-1287. [CrossRef]

82. Haußmann, B.I.G.; Parzies, H.K. Methodologies for generating variability. Part 1 Use of Genetic Resources in Plant Breeding. In Participatory Plant Breeding; Ceccarelli, S., Guimarães, E.P., Weltzien, E., Rajendran, P.G., Eds.; FAO: Rome, Italy, 2009; pp. 107-128.

83. Lin, B.B. Resilience in Agriculture through Crop Diversification: Adaptive Management for Environmental Change. Bioscience 2011, 61, 183-193. [CrossRef]

84. Reid, T.A.; Yang, R.C.; Salmon, F.D.; Spaner, D. Should spring wheat breeding for organically managed systems be conducted on organically managed land? Euphytica 2009, 169, 239-252. [CrossRef]

85. Löschenberger, F.; Fleck, A.; Grausgruber, H.; Hetzendorfer, H.; Hof, G.; Lafferty, J.; Marn, M.; Neumayer, A.; Pfaffinger, G.; Birschitzky, J. Breeding for organic agriculture: The example of winter wheat in Austria. Euphytica 2008, 163, 469-481. [CrossRef]

86. Riviere, P.; Goldringer, I.; Berthellot, J.F.; Galic, N.; Pin, S.; De Kochko, P.; Dawson, J.C. Response to farmer mass selection in early generation progeny of bread wheat landrace crosses. Renew. Agric. Food Syst. 2014, 30, 190-201. [CrossRef]

87. Döring, T.F.; Knapp, S.; Kovacs, G.; Murphy, K.; Wolfe, M.S. Evolutionary Plant Breeding in Cereals-Into a New Era. Sustainability 2011, 3, 1944-1971. [CrossRef]

88. Bedoussac, L.; Journet, E.-P.; Hauggaard-Nielsen, H.; Naudin, C.; Corre-Hellou, G.; Steen Jensen, E.; Prieur, L.; Justes, E. Ecological principles underlying the increase of productivity achieved by cereal-grain legume intercrops in organic farming: A review. Agron. Sustain. Dev. 2015, 35, 911-935. [CrossRef]

89. Desclaux, D.; Ceccarelli, S.; Navazio, J.; Coley, M.; Trouche, G.; Aguirre, S.; Weltzien, E.; Lançon, J. Centralized or Decentralized Breeding: The Potentials of Participatory Approaches for Low-Input and Organic Agriculture. In Organic Crop Breeding; van Bueren, E.L., Myers, J.R., Eds.; Wiley-Blackwell: Hoboken, NJ, USA, 2012; pp. 99-124.

90. Ceccarelli, S. Efficiency of Plant Breeding. Crop Sci. 2015, 55, 87-97. [CrossRef]

91. Campanelli, G.; Acciarri, N.; Campion, B.; Delvecchio, S.; Leteo, F.; Fusari, F.; Angelini, P.; Ceccarelli, S. Participatory tomato breeding for organic conditions in Italy. Euphytica 2015, 204, 179-197. [CrossRef]

92. Shelton, A.; Tracey, W.F. Recurrent selection and participatory plant breeding for improvement of two organic open-pollinated sweet corn (Zea mays L.) populations. Sustainability 2015, 7, 5139-5152. [CrossRef]

93. Pautasso, M.; Dehnen-Schmutz, K.; Ilbery, B.; Jeger, M.J.; Jones, G.; Little, R.; MacLeod, A.; Maye, D.; Parker, S.; Pietravalle, S.; Mills, P. Plant health challenges for a sustainable land use and rural economy. CAB Rev. 2012, 7, 63. [CrossRef]

94. Mokuwa, A.; Nuijten, E.; Okry, F.; Teeken, B.; Maat, H.; Richards, P.; Struik, P.C. Processes Underpinning Development and Maintenance of Diversity in Rice in West Africa: Evidence from Combining Morphological and Molecular Markers. PLoS ONE 2014, 9. [CrossRef] [PubMed]

95. Coomes, O.T.; McGuire, S.T.; Garine, E.; Caillon, S.; McKey, D.; Demeulenaere, E.; Jarvis, D.; Aistara, G.; Barnaud, A.; Clouvel, P.; et al. Farmer seed networks make a limited contribution to agriculture? Four common misconceptions. Food Policy 2015, 56, 41-50. [CrossRef]

96. Kotschi, J.; Wirz, J. Who Pays for Seeds? Thoughts on Financing Organic Plant Breeding; Working Paper; AGRECOL and Section for Agriculture: Marburg, Germany; Dornach, Switzerland, 2015; Available online: http://www.agrecol.de/files/Kotschi_\&_Wirz\%20Engl_12_05_15.pdf (accessed on 29 August 2016). 
97. Garcia-Yi, J. Market-based instruments for the conservation of underutilized crops: In-store experimental auction of native Chili products in Bolivia. Sustainability 2014, 6, 7768-7786. [CrossRef]

98. Bjørnstad, А. 'Do Not Privatize the Giant's Shoulders': Rethinking Patents in Plant Breeding. Trends Biotechnol. 2016, 34, 609-617. [CrossRef] [PubMed]

99. Vanloqueren, G.; Baret, P.V. Why are ecological, low-input, multi-resistant wheat cultivars slow to develop commercially? A Belgian agricultural 'lock-in' case study. Ecol. Econ. 2008, 66, 436-446. [CrossRef]

100. Vanloqueren, G.; Baret, P.V. How agricultural research systems shape a technological regime that develops genetic engineering but locks out agroecological innovations. Res. Policy 2009, 38, 971-983. [CrossRef]

(C) 2016 by the authors; licensee MDPI, Basel, Switzerland. This article is an open access article distributed under the terms and conditions of the Creative Commons Attribution (CC-BY) license (http:/ / creativecommons.org/licenses/by/4.0/). 